\title{
$\mathrm{Al}-\mathrm{Mg}-\mathrm{Si}$ 合金の疲労破壊に伴う水素集積の可視化
}

\author{
堀川 敬太郎* ·竹内 祐介 $* *$ *吉田 憲一 *** ·小林 秀敏*
}

Journal of Japan Institute of Light Metals, Vol. 56, No. 4 (2006), pp. 210-213

\section{Visualization of hydrogen during fatigue fracture in an Al-Mg-Si alloy}

Keitaro HORIKAWA*, Yusuke TAKEUCHI**, Kenichi YOSHIDA*** and Hidetoshi KOBAYASHI*

\begin{abstract}
Hydrogen accumulation during fatigue of a bake-hardened $\mathrm{Al}-\mathrm{Mg}-\mathrm{Si}$ alloy was investigated by means of hydrogen microprint technique. As a result of S-N curve relation as a function of testing frequency, effect of environmental hydrogen on fatigue properties was not clearly identified. Based on the low cycle fatigue test with $60 \mathrm{MPa}$ stress amplitude, it was revealed that hydrogen was accumulated on slip bands and that distribution of hydrogen emission was changed in the crack propagation direction. Hydrogen was preferentially accumulated at the coarse slip bands near the fatigue crack where the separation of slip planes was observed in the fracture surface. On the other hand, hydrogen was observed on the slip lines arranged like steps where the fatigue striations were formed in the fracture surface. At near the final fracture area where the fine slip bands were formed on specimen surface, hydrogen was arranged on each slip bands formed by multiple slips.
\end{abstract}

(Received August 22, 2005 Accepted November 21, 2005)

Keywords: Al-Mg-Si alloy, fatigue, hydrogen, visualization, slip band

\section{1. 緒言}

近年，軽量化による自動車の燃費向上を目的として，6000 系 Al-Mg-Si 系合金が自動車用ボディ材料として利用されて いる。自動車ボディ材として $\mathrm{Al}-\mathrm{Mg}-\mathrm{Si}$ 合金が利用される場 合, 溶体化処理後, $\mathrm{T} 4$ 処理状態で成形加工され, 塗装焼付 （BH）処理による $170 \sim 180^{\circ} \mathrm{C}$ で短時間（0.5h）の熱履歴を経 て, 時効硬化で強度が高められる ${ }^{1)}$ 。

この亜時効段階で使用される $\mathrm{Al}-\mathrm{Mg}-\mathrm{Si}$ 合金では，室温大 気中の低ひずみ速度引張試験（SSRT）によって試験環境の 水蒸気成分から材料中に取り込まれる水素の作用によって水 素脆化現象（環境脆化）が顕著となることが報告されてい $3^{2)}$ 。この環境脆化は, 一般に粒界破壊を伴い, 銅やシリコ ンなどの合金組成の違いによっても，その脆化の程度が異な

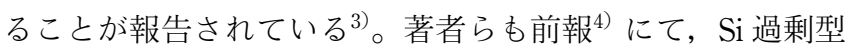
$\mathrm{Al}-\mathrm{Mg}-\mathrm{Si}-\mathrm{Cu}$ 合金に低ひずみ速度引張試験を行った場合に粒 界に水素集積が生じていることを水素マイクロプリント法 (HMT) で直接示している。

このように $\mathrm{Al}-\mathrm{Mg}-\mathrm{Si}$ 合金に引張变形を与えることによっ て最終破断部に水素集積が生じることが報告されており, 疲 労変形でも同様に変形が集中する箇所への局所的な水素集積 が生じる可能性も考えられるが，これまでアルミニウム合金 の疲労变形・破壊の過程で材料中の水素を可視化した報告は みられない。そこで本研究では, 過剩 $\mathrm{Si}$ 組成の $\mathrm{Al}-\mathrm{Mg}-\mathrm{Si}-\mathrm{Cu}$ 合金を用いて BH 処理材の疲労特性を調査するとともに, 疲
労変形中の水素集積挙動を HMT で可視化する試みを行った。

\section{2. 実験方法}

\section{1 疲労試験片}

供試材は合金組成 $\mathrm{A} 1-0.70$ mass $\% \mathrm{Mg}-0.76$ mass $\% \mathrm{Si}-$ $0.34 \mathrm{mass} \% \mathrm{Cu}$, 板厚 $1 \mathrm{~mm}$ の圧延板である。合金中に含まれ る不純物 $\mathrm{Fe}$ 量は 0.03 mass $\%, \mathrm{Mn}, \mathrm{Cr}$ 量は 0.01 mass $\%$ 未満で ある。これらの供試材から, 試験片の長手方向が圧延方向に 対して垂直方向（LT）になるように, 引張試験用の板状試験 片（平行部長 $50 \mathrm{~mm}$, 板幅 $15 \mathrm{~mm}, \mathrm{R} 25$ ）および, 疲労試験 用に平行部中央部に片切欠きを有する板状試験片をそれぞれ 放電加工機で切出した。疲労試験片の切欠き底部の曲率半径 は $100 \mu \mathrm{m}$ である。実験に用いた疲労試験片の形状および寸 法はFig. 1 に示す通りである。溶体化処理は大気炉を用いて 行い, $540^{\circ} \mathrm{C}$ で 1 時間保持後, 水中に焼入れた。試料は溶体 化処理後, 室温 (約 $25^{\circ} \mathrm{C}$ ) で 7 日保持（T4）後, 引き続い て, $\mathrm{BH}$ 処理に相当する $175^{\circ} \mathrm{C}$ で 30 分の人工時効処理を行っ た。BH 処理後の平均結晶粒径は約 $250 \mu \mathrm{m}$ である。熱処理 後, 試験片評点部の表面を 1500 番までのエメリー紙研磨の 後, バフ研磨および電解研磨により鏡面に仕上げた。 $\mathrm{T} 4$ 後 に $\mathrm{BH}$ 処理を行った試料の引張特性は， $0.2 \%$ 耐力： $127 \mathrm{MPa}$, 引張強さ：235 MPa, 破断伸び： $23 \%$ であった。

\section{2 水素マイクロプリント法}

熱処理, 鏡面研磨後の試験片表面に対して, ゲル状の原子 核乳剤（Ilford L4, 粒子径 $0.11 \mu \mathrm{m}$ ）を温水中で溶融した後,

\footnotetext{
* 大阪大学大学院基礎工学研究科機能創成専攻（～５60-8531 大阪府豊中市待兼山町 1-3）。Graduate School of Engineering Science, Osaka University（1-3 Machikaneyama, Toyonaka-shi, Osaka, 560-8531).

***徳島大学大学院機械工学専攻〔現在：昭和電工(株)〕School of Mechanical Engineering, Tokushima University（Tokushima-shi, Tokushima） 〔Present: Showa Denko K.K. 〕。

**** 徳島大学工学部機械工学科 (徳島市)。Department of Mechanical Engineering, Tokushima University（Tokushima-shi, Tokushima).
} 

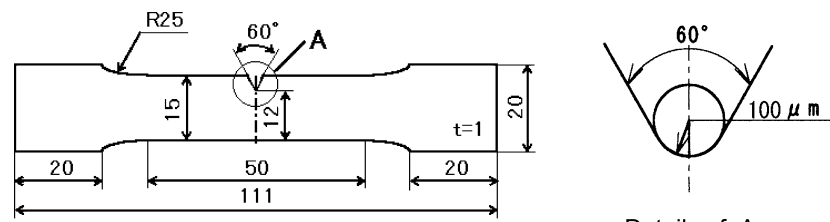

Details of $A$

Fig. 1 Configuration of fatigue specimen.

同温度の純水で 2 倍希釈した。ニクロム線で作製したワイ ヤーループを用いて, 試料表面を乳剂皮膜で被覆した。破断 後, 乳剂膜に含まれるゼラチン層を硬化させる目的でホルム アルデヒド溶液に 30 秒浸漬した。濃度 $15 \%$ のチオ硫酸ナト リウム水溶液中で弱擋拌を加えながら 3 分間定着処理を行う ことにより，未反応の臭化銀を除去した。定着処理後，試料 表面を水洗し冷風乾燥を行った。

\section{3 疲労試験および組織観察}

試験装置には電気油圧式疲労試験機（最大荷重 $5 \mathrm{tf}$ ）を使 用した。疲労試験は相対湿度約 $50 \%$ の試験雾囲気中にて行 い, 軸力荷重制御 (正弦波), 引張の片振り（応力比 $R=0$ ), 試験周波数は $2 \mathrm{~Hz}$ と $15 \mathrm{~Hz}$ の 2 条件で行った。疲労き裂先端 部で小規模降伏条件が満たされていると仮定して, 今回, 線 形破壊力学を用いた解析を試みた。き裂長さに対する応力拡 大係数の值は次式 ${ }^{5)}$ を用いて算出した。

$$
K=\sigma \sqrt{\pi a} \times F(a / W)
$$

ここで, $K$ は応力拡大係数， $\sigma$ は応力, $a$ はき裂長さ, $W$ は試験片幅, $F(a / W)$ は試験片形状に応じた補正係数であ る。

なお疲労き裂長さの測定は CCD カメラを用いて行った。疲 労試験後, 走査型顕微鏡（FE-SEM, Hitachi-S4700）を使用し て破断面および平行部表面の組織観察を行った。HMT の組 織で観察される銀粒子の同定には FE-SEM に付帯するエネル ギー分散型 X 線回折装置（EDXS）を用いた。

\section{3. 実験結果および考察}

\section{1 疲労特性}

疲労周波数を $2 \mathrm{~Hz}$ と $15 \mathrm{~Hz}$ で行った疲労試験で得られた S-N 曲線を Fig. 2 に示すが，各応力振幅において疲労寿命へ の周波数の影響は観察されなかった。そこで以下では応力振 幅 $60 \mathrm{MPa}$, 試験周波数 $15 \mathrm{~Hz}$ の疲労について検討を進めるこ とにする。応力振幅 $60 \mathrm{MPa}$ の疲労試験を行った場合のき裂 進展速度と応力拡大係数の関係を Fig. 3 に示す。疲労き裂進 展特性は, き裂, 安定成長, 最終破断に対応する 3 つの領域 に分けられることがわかる。き裂が安定的に進展する中間領 域の関係をパリス則 $d a / d N=C(\Delta K)^{m}$ に代入するとべき数 $m$ として約 2.0 という值が得られ, 一般的なアルミニウム合金 の疲労で報告 ${ }^{6)}$ されている值とほぼ一致する。

\section{2 破面観察}

応力振幅 $60 \mathrm{MPa}$, 周波数 $15 \mathrm{~Hz}$ の疲労試験で破断させた場 合の破面を Fig. 4 に示すが，切欠き底部領域より離れるに従 い，階段状の平滑な領域（Fig. 4 (a))，すべり面分離とスト ライエーションの混在領域 (Fig. 4 (b)), ストライエーショ ン領域（Fig. 4 (c)), 延性ディンプル領域（Fig. 4 (d)), がそ れぞれ観察される。また Fig. 4 (a) で示した領域の切欠き底

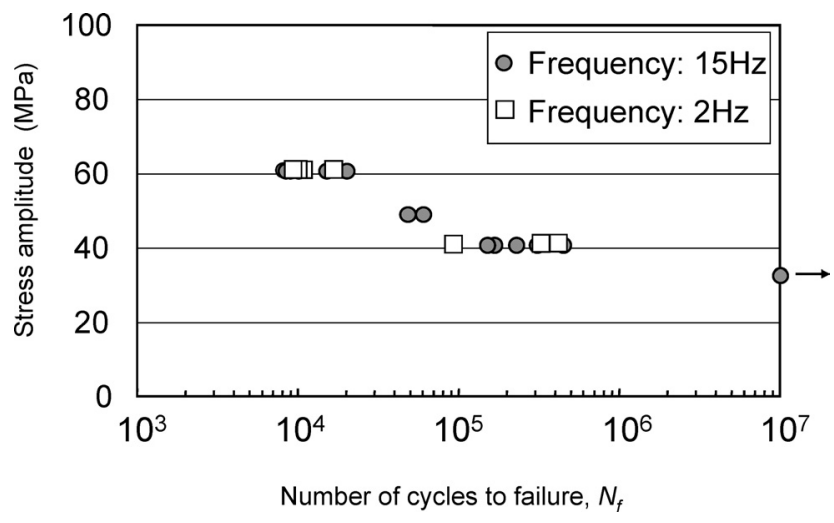

Fig. 2 Stress amplitude vs. number of cycles to fracture for a BH-treated $\mathrm{Al}-\mathrm{Mg}-\mathrm{Si}$ alloy.

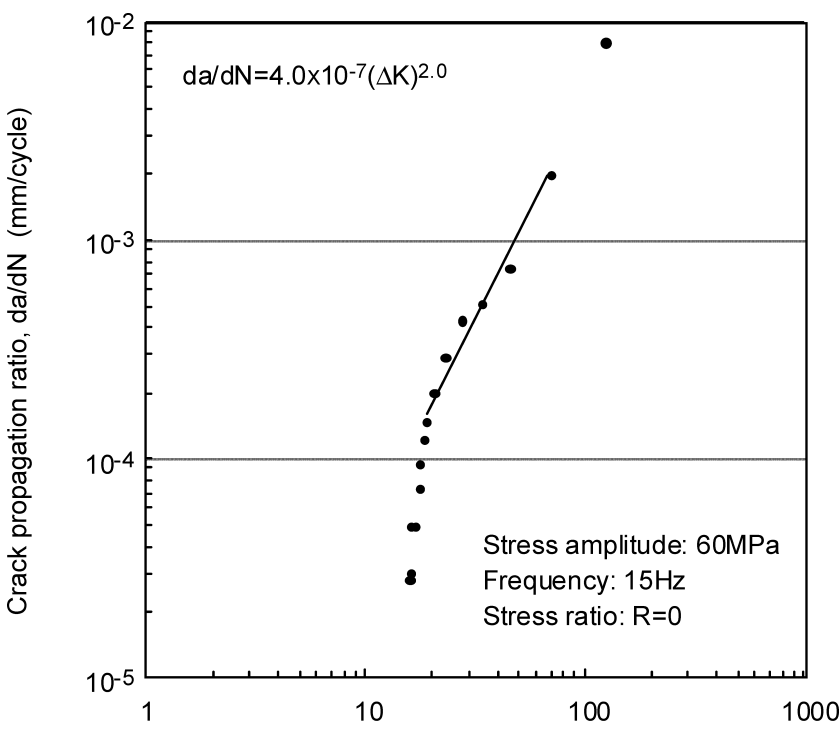

Stress intensity factor range $\Delta K(\mathrm{MPa} \sqrt{\mathrm{m}})$

Fig. 3 Crack growth rate plotted as a function of the stress intensity factor range of a $\mathrm{BH}$-treated $\mathrm{Al}-\mathrm{Mg}-\mathrm{Si}$ alloy.
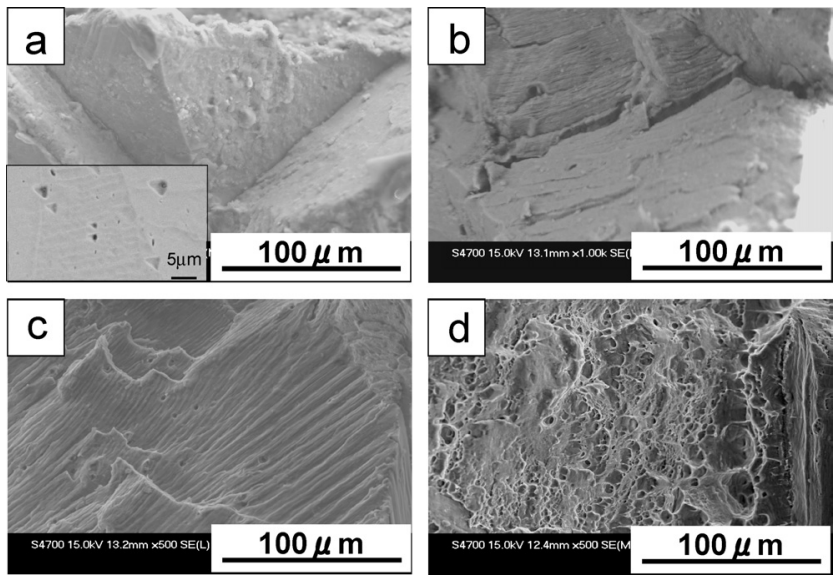

Fig. 4 Fracture surfaces near the notch front (a), fatigue crack (b), striation (c) and ductile dimples (d).

部の平滑部にみられる三角形形状の腐食ピットより, 観察さ れる平滑面は（111）すべり面であることがわかる。

\section{3 HMT 組織}

Fig. 4 の各領域に対応する部位に隣接する試験片平行部を 

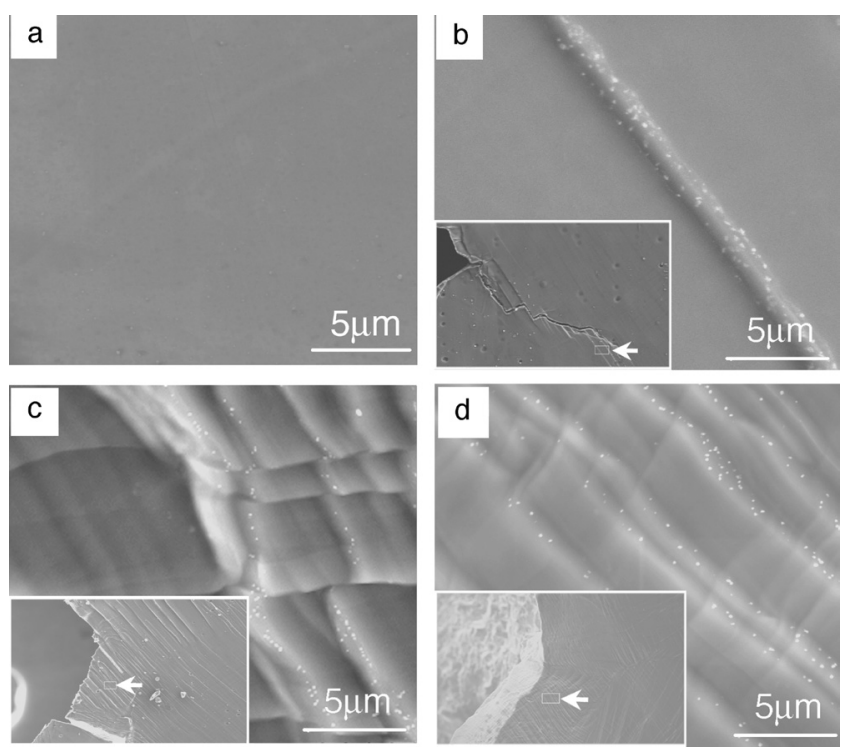

Fig. 5 HMT images adjacent to the notch front (a), fatigue crack (b), striation (c) and ductile dimples (d).

HMT で調べた結果を Fig. 5 にそれぞれ示す。Fig. 5 (a) に示 す切欠き底のごく近傍では, すべり帯および水素の集積を示 す銀粒子はほとんど観察されなかった。一方，切欠き底から き裂伝播方向に $2 \mathrm{~mm}$ 変位したすべり面分離が観察される領 域の付近（Fig. 5 (b)）では, 破断の主き裂より分岐した疲労 き裂が観察され, そのき裂先端より伸びる粗大なすべり帯上 に多くの銀粒子の優先集積が観察された。粗大すべり帯の長 手方向に対して垂直となる方向においても銀粒子の分布が明 瞭に観察される。Fig. 5 (c) に示すストライエーションが破 面に観察される領域に隣接する試験片平行部では, すべり帯 同士の交差が多く観察され，銀粒子はそれらの交差したすべ り帯上に階段状に観察された。破面に延性ディンプルを呈し た最終破断領域に隣接する表面では, 多重すべりによって形 成された微細すべり帯上に銀粒子の集積が観察される（Fig. $5(\mathrm{~d}))$ 。この微細すべり帯に観察される銀粒子の分布をみる と, ある優先的な配列方向のすべり帯に集中して銀粒子が集 積していることがわかる。Fig. 6 に示すように最終破断部か ら試験片長手方向に变位して観察した場合においても, 離れ るに従って観察される銀粒子の数密度の減少がみられるもの の, 特定の方向のすべり帯に多くの銀粒子が観察される。こ れらの傾向は周波数 $2 \mathrm{~Hz}$ の試験でも同様であった（Fig. 7)。

\section{4. 考察}

切欠きを持つ $\mathrm{Al}-\mathrm{Mg}-\mathrm{Si}$ 合金 $\mathrm{BH}$ 材に対して疲労変形を与 えた場合の水素集積を，これまでの報告と比較，検討してみ る。まず，切欠き底直下および疲労分岐き裂が観察された切 欠き周辺部近傍をみると, き裂周辺部の粗大すべり帯に限定 されて水素の集積が観察されており，それ以外では銀粒子の 分布はみられなかった。Lufrano と Sofronis ${ }^{7)}$ はき裂および切 欠き先端の水素分布を計算するために, 有限要素法による塑 性変形之水素拡散の連性解析を行い, 応力集中部への応力誘 起拡散と転位によるトラップ効果のいずれの水素濃化機構が より支配的であるか検討している。切欠きの曲率半径が板幅 に対して小さい場合, き裂先端領域では転位による水素卜 ラップが水素濃化の支配的な機構となり, 応力集中による応
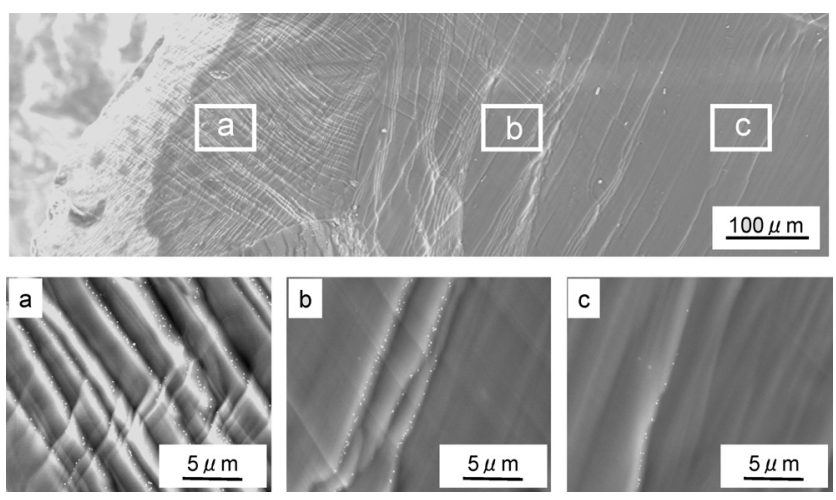

Fig. 6 HMT images in the longitudinal direction near the final fracture point (a), (b) and (c).
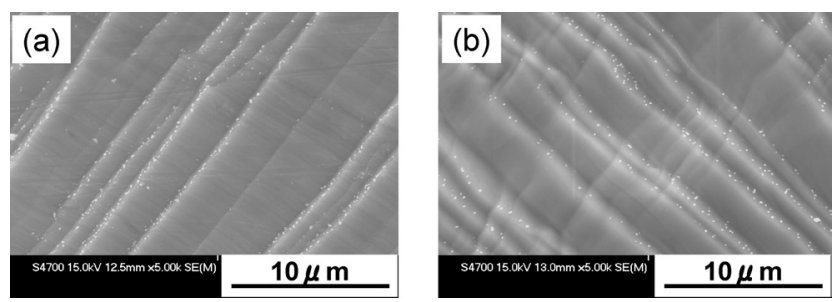

Fig. 7 HMT images near the final fracture point, test frequency: $2 \mathrm{~Hz}$ (a) and $15 \mathrm{~Hz}$ (b).

力誘起拡散の程度は大きくないことを報告しており, 今回得 られた切欠き周辺での水素集積の形態と一致している。逆に 切欠き底の曲率半径が大きい場合は，転位による水素トラッ プと応力誘起拡散とが競合し, 水素濃化領域が切欠き底の塑 性域か三軸応力集中部になるとしている。したがって切欠き の曲率と応力に依存して水素の濃化形態が変化することも予 想されるが, その点についてまでは本研究では追求しなかっ た。

また, 疲労き裂の先端に伸びる粗大すべり帯は引張变形の 最終破断部で報告されるむのと比較して幅が広く $(2 \sim 3 \mu \mathrm{m})$, 粗大すべり帯の長手方向に対して垂直となる方向の水素分布 屯識別できる。この幅方向の水素分布より, 同じすべり帯内 で, 同一方位でかつ異なるすべり面上を運動した複数の転位 が水素をトラップしたまま表面まですべり運動しているもの と推測される。

一方，疲労き裂の安定成長の過程で Fig. 5 (c) に示すよう に破面にストライエーションが観察される領域近傍の表面で は, 水素の分布がすべり帯によって分断され, 階段状に集積 している。この領域では, Fig. 8 に示すように破断部から離 れる箇所でも, すべり帯同士の交差によって生じた段差がみ られるが，すべりがより多く生じたと思われる，ある優先的 な方向を持ったすべり帯により多くの銀粒子が観察された。 ストライエーションはき裂先端の塑性鈍化と再鋭化の繰返し で形成され, その前縁では $2 つ$ すべり面の交互せん断に よって 2 重すべりが発達するといわれている ${ }^{8)}$ 。今回観察さ れた階段状の水素の分布は, その交互すべりが発達する過程 での水素放出を捉えたものと考えられる。なお, 観察される 水素の放出には優先的な方向がみられるが，これは前に述べ た粗大すべり帯の場合と同様に, 同一方位で異なるすべり面 上を運動した転位が水素を運搬していることが示唆される。

Fig. 5 (d) やFig. 8 に示したように, 疲労き裂進展速度が 


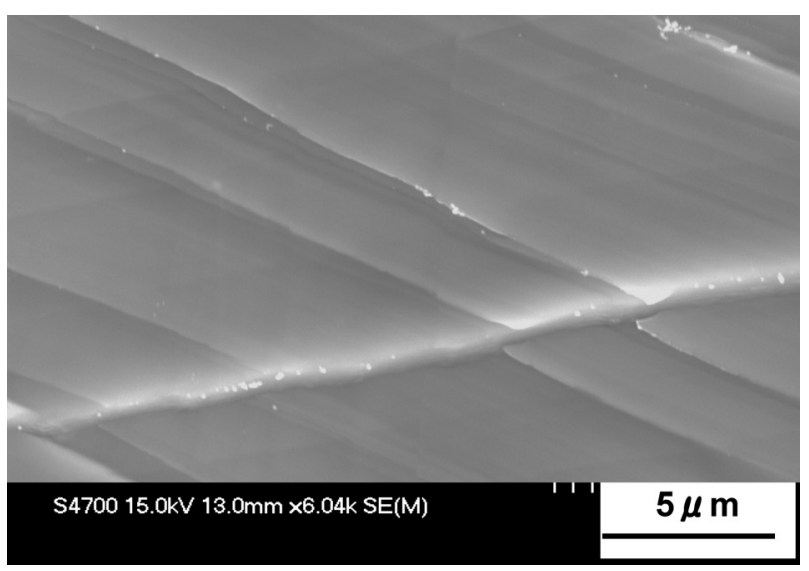

Fig. 8 A HMT image showing the intersection of slip bands and accumulation of silver particles.

上昇し, 最終破断にいたる領域に隣接する表面では, 多重す べりによって生じた微細すべり帯上に水素の集積が観察され た。この領域の組織は他のアルミニウム合金を引張破断させ た場合にみられる HMT 組織 9),10) に近いが，ここで観察され る組織についても前に述べた組織と同様に，水素の放出に対 して優先的な方向がみられた。

すべてのすべり方向で水素の放出がみられなかった一因と して, HMT での水素検出効率が関係していると思われる。 HMT は原理的には水素原子 1 つ 銀イオンとの反応で検知 できる手法であるが，Ichitani ら ${ }^{11)}$ は実際の試料表面から放 出される水素の $99 \%$ は表面で再結合し水素ガスとなるため銀 イオンの還元反応には寄与せず, 結果として HMT の水素検 出効率が $1 \%$ 程度となるとしている。この低い HMT の水素 検出効率を高手法として試料表面へのニッケルやパラジ ウムなどの金属コーティング処理が有効であると報告されて いる ${ }^{11)}$ 。そこで，アークイオンプレーティング装置を用いて アルゴン雾囲気中で試料表面にあらかじめ厚さ約 $20 \mathrm{~nm}$ のす ず層をコーティングし，同様に HMT で疲労最終破断部の観 察を行った。その結果, Fig. 9 に示すように観察される銀粒 子の分布密度が大幅に高まり, 観察されるすべてのすべり方 向で銀粒子の分布が確認できた。今回すずのコーティングに よって HMT の水素検出効率が向上する機構の詳細は不明で あるが，プレーティング前のアルゴンイオンスパッタリング による酸化膜の除去とすず層の形成によって試料表面での水 素原子の再結合が抑制されたものと考えられる。以上のこと から, 破断部近傍では, すべり帯での水素の集積挙動にはす べり方向による程度の差があるものの, 表面に観察される大 部分のすべり帯で水素の集積が生じているものと判断される。

\section{5. 結言}

Al-Mg-Si 合金 BH 処理材の疲労試験中の水素放出挙動を 水素マイクロプリント法により調查した結果, 次のことが明 らかになった。

（1）試験周波数 $2 \mathrm{~Hz}$ と $15 \mathrm{~Hz}$ の違いによる S-N 特性に対す

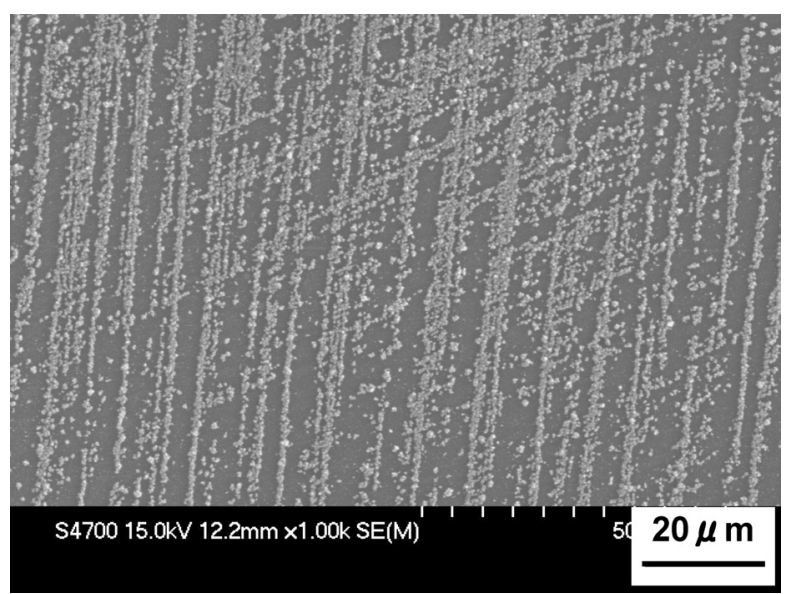

Fig. 9 A HMT image near the final fracture area coated with tin by arc-ion-plating.

る環境水素の影響はほとんどみられない。

（2）疲労変形を与えた場合でも，引張変形の場合と同じく 材料表面のすべり帯に水素が集積する。絽返し応力の付加に よって材料中の水素は転位にトラップされて, すべり変形に よって表面まで運搬されているむのと考えられる。

（3）切欠き底部周辺では, 水素の集積は粗大すべり帯上に 限定されており, それ以外での水素の集積は比較的少ない。 ストライエーションが伝播する安定き裂伝播領域に隣接する 表面では, 水素の放出は交差するすべり帯に階段状に観察さ れる。き裂進展速度が上昇する最終破断部の近傍では, 微細 な多重すべり帯上に水素の集積が認められる。

\section{謝 辞}

本研究は, 日本アルミニウム協会, 平成 16-17 年度「アル ミニウム研究助成事業」により行われたあのであり,ここに 感謝の意を表します。また研究の一部は, 財団法人軽金属奨 学会の研究教育資金によって行われたことを記し感謝の意を 表します。

\section{参 考 文 献}

1）軽金属学会編：自動車軽量化のための生産技術，(2003).

2）倉本 繁, 謝 明君, 菅野幹宏 : 軽金属, 52 (2002), 250255.

3）大崎修平, 木下勝之：軽金属，53（2003）, 157-162.

4）堀川敬太郎, 吉田憲一, 大森章弘, 坂巻清司：軽金属, 53 (2003), 147-151.

5）岡村弘之：線形破壊力学入門，培風館，(1976)。

6）東郷敬一郎：材料強度解析学, 内田老鶴围, (2004).

7) J. Lufrano and P. Sofronis: Acta Matererialia, 46 (1998), 1519-1526.

8) P. Neumann: Acta Metallurgica, 17 (1969), 1219-1225.

9）小山克己，伊藤吾朗，菅野幹宏：日本金属学会誌，62（1998）, 790-795.

10) K. Horikawa and K. Yoshida: Materials Transactions, 45 (2004), 315318.

11) K. Ichitani, S. Kuramoto and M. Kanno: Corrosion Science, 45 (2003), 1227-1241. 